MEUCCI, Simone. Institucionalização da sociologia no Brasil: primeiros manuais e cursos. São Paulo: Hucitec: Fapesp, 2011. 169 p.

\section{Amurabi Oliveira}

O livro de Simone Meucci é lançado num momento demasiadamente oportuno, quando consideramos o próprio processo de reintrodução da Sociologia no Ensino Médio, mas não só. Pois, muito além de uma pesquisa voltada para a Sociologia da Educação, a presente obra constitui uma Sociologia dos Intelectuais, a partir de uma construção teórica que vai para além de uma revisita aos primeiros manuais de sociologia produzidos no Brasil. Ela analisa o próprio movimento de institucionalização da Sociologia, entre as décadas de 20 a 40, do século XX.

O olhar lançado traz um traço eminentemente original, por caminhar na contramão da maior parte dos estudos que se debruçam sobre a institucionalização da Sociologia no Brasil, e se referenciam a esse processo, quase que exclusivamente, a partir da Universidade, com início nos anos 30. Meucci traz uma análise acerca do processo de institucionalização e rotinização do conhecimento sociológico ao longo das décadas de 20, 30 e 40, incluindo, aí, autores menos consagrados que atuaram nessa seara.

A autora destaca que, a partir dos anos 30 , houve uma explosão de manuais de Sociologia. Entre os anos de 1931 e 1945, ela levanta 35 títulos, incluindo tanto autores "desconhecidos", como outros mais ilustres, como Fernando de Azevedo, Delgado de Carvalho, Amaral Fontoura e Gilberto Freyre. São apontadas como razões que viabilizaram tal profusão tanto a consolidação da Sociologia no sistema de ensino, nesse período, quanto um mercado editorial favorável ao investimento na área pedagógica. No ímpeto de ir para além de um olhar sobre os manuais, Meucci investiga quem eram os sujeitos envolvidos na tarefa de sistematizar esse conhecimento sociológico, os quais apresentam algumas características distintivas, como o fato de gravitarem em torno do Estado, bem como de estarem envolvidos no debate educacional. Em meio a esse cenário, é levantada a hipótese de que: “[...] a Sociologia passou a se constituir como uma linguagem importante, por meio da qual se traduziram os embates fundamentais do período. [...] O discurso sociológico era então a força atuante e decisiva nos debates da época." (Ibidem, p. 42). Devido a esse fato, teria conseguido mobilizar tantos intelectuais brasileiros do período.

Também há uma preocupação em desvendar que significado a sociologia passou a ter quando introduzida no país, apontando que, nesses ambientes intelectuais, em especial a partir das Faculdades de Direito, a Sociologia passou a ser apontada como a ciência capaz de esclarecer certas relações sociais, bem como foi compreendida como a disciplina capaz de renovar a formação intelectual das Faculdades de Direito no país, chegando, em última instância, de acordo com intelectuais como Pontes de Miranda, a beneficiar a instituição de uma "política positiva".

Ao contrário do ensaísmo jurídico e literário, a Sociologia seria capaz de renovar a vida intelectual, através do seu realismo científico, o que seria propiciado, de acordo com o que era proposto pelos manuais, através de um papel ativo do professor, substituindo a longa e abstrata preleção por atividades que despertassem, nos alunos, o interesse pelas questões sociais, através de seminários, debates, pesquisas etc. A Sociologia parecia, nesse momento, opor-se ao próprio modelo bacharelesco presente na formação intelectual ofertada nas Faculdades de Direito, responsável pela principal causa da inoperância política: o divorcio entre o modelo político e a realidade social do país. 
Esse cenário de mudança no ambiente intelectual brasileiro é marcado pela própria guinada na percepção do lugar dos intelectuais na sociedade brasileira. É um momento em que as reformas na educação passaram a ser percebidas como uma reforma da própria sociedade, e os intelectuais envolvidos passaram a se reconhecer como elementos ativos na obra de formação da nação. É nesse bojo de transformações, que a Sociologia, nos cursos de formação de professores (então denominados cursos normais), juntamente com outras disciplinas, como metodologia do ensino, psicologia etc., visavam a dar mais cientificidade e pragmatismo ao âmbito da formação docente. A introdução da Sociologia como disciplina indispensável para a formação de educadores se vincula ao próprio movimento da Escola Nova, que tinha então, na década de 20 e 30, grande repercussão no meio intelectual brasileiro.

A autora levanta uma interessante hipótese acerca das expectativas depositadas na Sociologia e na própria tarefa dos educadores, que teriam sua origem na noção de que o Brasil seria um país inconcluso. "Ou seja, tratava-se de um país em que a unidade entre sociedade e nação não tinha sido efetivamente completada.” (Ibidem, p. 68).

Nesse momento, a Sociologia, em especial através de seus manuais, torna-se palco de uma intensa batalha entre aqueles vinculados à Escola Nova, representados principalmente por Fernando de Azevedo, e a pedagogia católica, representada por Amoroso Lima, para quem a Sociologia seria, acima de tudo, uma disciplina moral. Para Meucci, os livros de Sociologia Cristã que emergem nesse período podem ser compreendidos como resultado de uma reação às transformações da sociedade, as quais, supostamente, pareciam pôr em risco o ideário católico. Os livros de Sociologia tornam-se, portanto, veículos de expressão de um debate político sobre a natureza da sociedade e da educação.

Outro aspecto trazido pela autora é a centralidade que a perspectiva teórica de Durkheim vai tomar nesse período, encontrando eco, prin- cipalmente, através de Fernando de Azevedo. Tal intelectual trata, ainda, de apresentar a figura do sociólogo, ao contrário da Sociologia, bastante conhecida através do sistema de ensino. A Sociologia e o sociólogo são apresentados como agentes e como produtos do progresso, e, portanto, o processo de institucionalização dessa ciência no Brasil mostrava-se favorável ao desenvolvimento do país. Outro ponto interessante destacado nessa obra é a singularidade da sistematização de Freyre da Sociologia, realizada através de manuais, que se origina no próprio caráter sui generis da sua formação intelectual. Ele era o único do período, dentre os autores analisados, com uma formação acadêmica em ciências sociais, bem como aquele que faz referências a autores para além do mundo anglo-francófono. Para Freyre, da mesma forma que não havia uma única Sociologia, não havia um único modelo de modernidade possível. Nesse período, na interpretação da autora, os livros de Sociologia expressariam as forças atuantes que disputavam o monopólio da explicação da sociedade.

Por fim, a autora aponta para conceitos-chave para a compreensão do debate retratado através dos livros didáticos: progresso, e organização social. Dentro da noção de progresso, destaca-se a perspectiva teórica apregoada por Spencer, aquela que encontrou mais receptividade entre os primeiros sistematizadores e "rotinizadores" do conhecimento sociológico, o que ocorreu, principalmente, durante o período do Estado Novo. Nesse ponto, a autora nos chama a atenção para o fato de essa formulação estar em consonância com o pacto nacional que era então alinhavado. No que tange ao conceito de organização social, ela chama a atenção para o fato que se buscava impor, por meio do ensino de Sociologia, um padrão de organização social, propondo, assim, um homem novo para um Estado novo.

Meucci destaca, ao longo de sua obra, como a sociologia foi encarada com otimismo por parte dos mais diversos segmentos intelectuais brasileiros, apontada como a disciplina que seria capaz 
de renovar intelectual e socialmente o país, pois teria as ferramentas científicas para tanto. Sua obra tem como grande contribuição a investigação do debate intelectual envolto no processo de institucionalização da Sociologia no Brasil, observado a partir de um ângulo pouco explorado, ou seja, a partir dos primeiros manuais, abrindo outras possibilidades de análise e, mesmo, de indagação em torno da institucionalidade da Sociologia no cenário atual.

(Recebido para publicação em 17 de outubro de 2011) (Aceito em 03 de janeiro de 2012)

Amurabi Oliveira - Doutor em Sociologia. Professor da Universidade Federal de Alagoas. Editor da REALIS Revista de Estudos AntiUtilitaristas e PosColoniais. Possui experiência na área de sociologia, de antropologia e de educação, com ênfase em: prática de pesquisa no ensino de sociologia no ensino médio e na área de sociologia e antropologia da religião. Atua principalmente nos seguintes temas: Religiosidades, Nova Era, Novos Movimentos Religiosos, Vale do Amanhecer, Educação, Sociologia e Antropologia da Educação, Ensino de Sociologia, Dádiva, Estudos Pós-Coloniais. amurabi_cs@hotmail.com 